\title{
The Peculiarities of the Political Vocabulary in French and Georgian Languages
}

\author{
Ketevan Djachy \\ Romance Department, College of Arts and Sciences, Ilia State University, Georgia \\ Mariam Pareshishvili \\ University of Patriarchate of Georgia
}

\begin{abstract}
Political language represents one of the complex specialized languages considering the complexity of socio-political texts. Some scholars distinguish between "the language of politics" and "political language", stating that the former contains the terminology and rhetoric associated with political activities employed by politicians while playing their roles in politics; it is characterized by an extreme flexibility and dynamizm. As for the "political language", it is open to all members of the linguistic community. It is related to the specific use of a common language as a means of persuasion and control. In other words, it is the language used for the purpose of manipulation. We think that these two terms are somehow interconnected. Both of them serve the purpose of manipulation. Therefore, they can be considered as partial synonyms. The article aims to discuss the French and Georgian political vocabulary in order to identify the specific characteristics of each and also to define the status of French lexical units for the purpose of their correct interpretation and expression in the Georgian language.
\end{abstract}

Index Terms - political terminology, realia, political language, political discourse, imprecision

\section{INTRODUCTION}

Political changes that took place in the $20^{\text {th }}$ and $21^{\text {th }}$ centuries had a significant effect on the existing communication systems and contributed to the emergence of a new terminology. In fact, language is not an unchangeable phenomenon; it permanently undergoes changes especially at the level of vocabulary. Every year new concepts and realia appear in any language, which have to be correctly transferred from one language to another, in order to keep a language alive and have a language that possesses the ability to express the modern world with all its diversity and complexity. For the purpose of denoting new political and technical realia, new words are borrowed from foreign languages.

Terminology has a long-standing tradition, as people are normally in need of denominating the realites existing around them, classifying constituent elements of these realities and establishing connection between the different concepts used by different linguistic groups. Terminology is an interdisciplinary crossroads where studies concur - a crossroads which consists of three components: theoretical, descriptive and applied components. (Cabré, 1998, p.5).

According to this definition, it refers to an independent field characterized by certain features. It is interdisciplinary. It is independent because it has its own subject matter and methods of study.

Modern political terminology is quite problematic. The term 'politics' is derived from the Latin word politicus (relating to the management of people), which itself is borrowed from Greek language (in Greek meaning the citizens of a state). Its use as a noun dates back to the $16^{\text {th }}$ century, which originaly meant 'a police officer'. Many other words originated from this word. The word 'politics' has many meanings. It denotes a power, but at the same time it implies the principle of organizing social order. As a power, politics recognizes only one rule, maintaining the power by those who possess it. (Tenzer 1991, p. 3).

Language and politics are closely connected to each other. Many researchers talk about the connection between them. Language is politics and politics is a language, since the government can not rely solely on physical and economic forces, it needs to harmonize the conduct of the classes of people exerting power. Language is not only a meanse of communication, but also a means of isolation. It is a means of expression, an instrument of manipulation. It is not just a tool for maintaining freedom but a tool for enslaving linguistic stereotypes as well. Finally, language is inseparable from politics, and understanding it correctly is possible only in this very context.

The extent of the power exerted by politicians is a function of the language used by these polititions and greatly depends on the professional use of this language, as a language is not only a meanse of exerting power, but an instrument as well. Policy makers need to know how to select the right words and expressions and make their thoughts and position understandable to the addressees. Language gains strength at the moment when people are using this power, since language does not have any power per se.

Political language is designed for political communication. We can as well talk about the possible creation of a new discipline, which is called linguistic political science. Some linguists believe that political language should be considered as a professional language - as a version of an official language. (Sheigal, 2000, p.19). 
The term "language of politics" is more common. It has a conventional character, and it is used not only to express special political vocabulary, but also to study its functioning in the discourse. In fact, unlike other areas of human activity, the specificity of politics is expressed in the nature of discourse characteristic to it. Many political actions represent discourses by their nature.

There is a close connection between discourse, ideology and politics, meaning that, in general, politics is of discourse nature as well as of ideological nature, and different ideologies are widely represented in the forms of texts and discourses. Traditionally, ideology is bluntly and negatively defined as a 'false belief'. Contemporary and multidisciplinary approach describes different ideologies as axiomic foundations for social performance shared by different groups of people. This general ideologies form the basis for groups having specific behavior, which in turn may influence individual opinions, understanding of specific events and behaviour of members of different groups; discourses as well as social practice involve members of a given group. Ideology plays its role in politics particularly it defines political system, organizations, movements, political practice and political knowledge. Hidden political ideology is typically expressed in political discourse when "own" positive qualities and negative qualities of "others" are strongly emphasized whereas "own" negative qualities and positive qualities of "others" are diminished. This kind of general strategy can be implemented at all levels of discourse (Teun Van Dijk, 2006, p.21).

Political discourse stands at the crossroads of different sciences, such as: social sciences, psychology, sociology, linguistics and even theology. Some people think that the rules and principles of the theory of communication regulate only the ability to lead a persuasive discourse. Discourse has different functions: 1 . structural: discourse is the building block of any political system; 2. decisive: in this case discourse plays the central role, as power always needs persuasion, inspiration, collecting and sharing information; 3. pedagogical function; 4. therapeutic function. Political discourse is a source of ideas and tries to eliminate any doubt. It permanently strives to make all real relationships rational.

Some scholars distinguish between the "language of politics" and "Political language." "Language of politics" is a structured system of symbols constituting semiotic space for political discourse. Political discourse covers acts of discourse, political articles, official texts concerning politics, scholarly articles on political and social life (Sheigal, 2000, p.22).

While studying political vocabulary, special attention is paid to the language of publications and it is natural, as the media creates new concepts, words and expressions. That is the language of the press, which allows us to detect the smallest semantic changes in the words and stylistic nuances.

Benoît Deshayes (2011, para 2), studying words do not make politics, but they help to ... No one has ever dared to say this out loud until now. Though, we should admit: modern politicians - men and women - are true mediators in communicating messages, which also includes selecting and using discourses, deciding where and how to publicize them effectively, ensuring their availability to as many people as possible. These are exactly the matters that concern, bother and fascinate all the men and women who govern us.

The language of politics is characterized by the features such as abstraction, complexity, ambiguousness, uncertainty, relativity, polysemy, the features that are characteristic of other lexico-semantic sub-systems, as well as the features that are characteristic of a general political vocabulary. Polysemy is ideologically stipulated by political objectives and not by the context.

Specificity of the language of politics lies in its function to serve as a means of expressing substantial political ideas held and practices carried out by a government. It also outlines axiological qualities of the language of politics (explicit or implicit). It strongly influences emotions rather than intellect.

The language of politics is characterized by extreme flexibility, mobility and dynamizm. It immediately reacts to any social change. Appearance of a new realia gives birth to new words and expressions. Old realia denote past events. Lexical units undergo semantic changes.

The second feature of the language of politics is semantic and stylistic openness, allowing introduction of other words belonging to social sphere in it. It should be noted that political language is broader than the notion of style. Its main area of functioning is political and social life. That is why political language has long been a focus of researchers.

\section{METHODOLOGY}

The research methodologies used in this study cover the metods of philological research and comparative research. Using this methodology we try to show similarities and differences in French and Georgian journalistic discourses as well as the stylistic-semantic characteristics of French and Georgian journalistic discourses.

Since the $90 \mathrm{~s}$ of the $20^{\text {th }}$ century, interest in politics has increased as a result of the political changes in our society. Researchers have been focused on political metaphors. Normally the studies of political discourse in the field of mass communication have been carried out in terms of efficiency of the influence of discursive practice.

Metaphor is a stylistic trope. It is of high significance for a text of any type: narrative, descriptive or argumentative. Metaphor enriches the text through emphasizing or diminishing the meaning of some words existing in the language.

Metaphor is pervasive in everyday life, not just in language but in thought and action. Our ordinary conceptual system, in terms of which we both think and act, is fundamentally metaphorical in nature. (Johnson \& Lakoff, 1985, p.13). 
According to Gilles Gauthier (Gauthier, 1994, p. 140), political discourse contains a lot of metaphorical expression. It contains the body-related metaphors (à la tête du parti ; le bras droit du président, sur un pied d'égalité); natural metaphors (un vent de changement ; la vague de l'élargissement), military metaphors (les troupes partisanes) and metaphors from the sphere of sports (l'équipe dirigeante). For example:

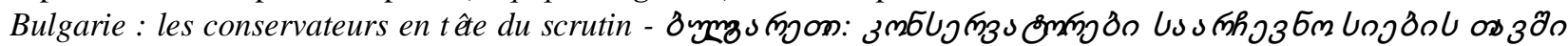
s nos 6 /Bulgaria: Conservatives head the election list/.

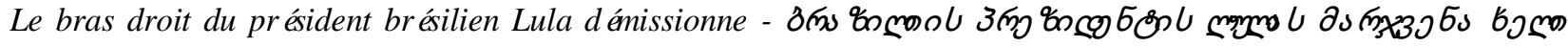
zu ç ç8 /The right-hand man of Brazilian President Lula resigns/.

Metaphors constantly undergo changes. Normally, political changes precede changes in metaphors. These changes are closely linked to the political context. Politicians tend to use stylistic means in their political discourses in order to ensure that their voters are impressed. Using stylistic tropes is one of the characteristic features of political discourse. Tropes represent the means of expression that are intended to cause emotions, impress, revive opinions expressed, convince, attract the attention of the addressees.

After "Rose Revolution" new metaphors were introduced in political discourse and in the press in Georgia. For

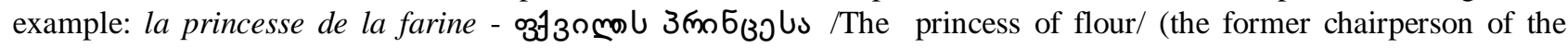
Parliament of Georgia, whose father had monopolized the business of flour); Umbolub bu moyo - oisillon de Soros / Soros's youngling/ (the former president of Georgia, who gained his post owing to billionaire George Soros);

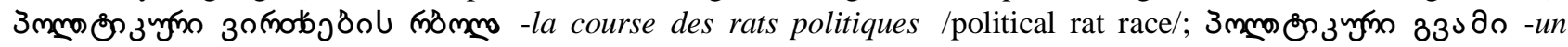

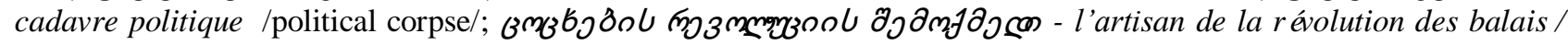

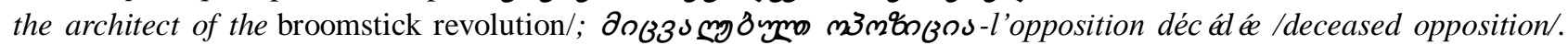

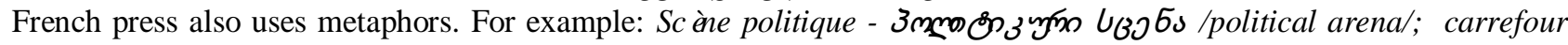

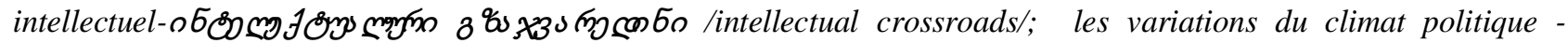

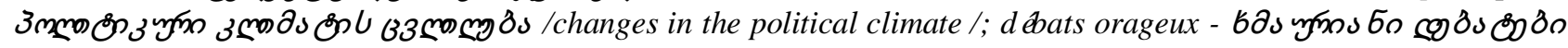
/stormy debates/.

Interest in politics has become apparent in lexicography. It should be noted that there are two types of dictionaries. First is the political dictionary, which is focused on explanation of notions rather than on explanation of words and expressions. The second type is the dictionary of politics, an explanatory dictionary, which pays special attention to the meanings of words and expressions.

Political life of the society undergoes changes and dictionaries reflect dynamic processes going on in the language but there is a chronological limit to political vocabulary. In 2006, we published the "Dictionary of French and Georgian political terms" in Georgia (Djachy, Pareshishvili, 2006). It includes 2025 words and phrases that are related to territorial, administrative and political systems, as well as diplomatic terms frequently used in the process of negotiations. The dictionary includes abbreviations that stand for some international organizations. These are very important organizations that have played significant role in international life. A list of countries with their capitals, organized in aphabetical order, is given in the appendix. We understand that the dictionary is not complete, given that new realia are introduced in French and Georgian political discourses on almost a daily basis. However, this dictionary proved to be of great help to those who are interested in learning French political vocabulary. It is especially useful for translators and interpreters.

\section{RESUltS AND ANALYSIS}

In order to collect and analyse political vocabulary a question needs to be answered: what is meant by this term? What are the criteria for determining what is to be included and what is not to be included in the political vocabulary?

Political vocabulary represents a set of words and formulae designed to be used not for the purpose of putting language in the service of existing reality, but for the purpose of performing a specific political function, putting existing reality in the service of language, more precisely putting existing reality in the service of politics through language. (Denquin, 1999, p.5).

The most important words are: droite, gauche, centre, cohabitation, présidentiable, etc. Georgian equivalents of

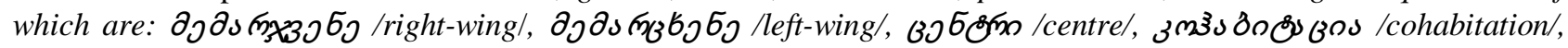
उங刀

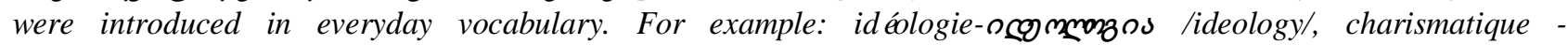
Ju no \&as onno /charismal, etc.

There is a difference between political vocabulary and the vocabulary of political science.

Political science uses words that describe the real world. It describes the condition of the subjects which might be true or false. Political vocabulary serves absolutely different goals that is wording of the statement, the purpose of which is not to describe the reality, it does not have the ability to be true or false. (Denquin, 1999, p. 4).

Benoit Deshayes (2011, para 2), studying and carefully examining verbal communication of many politicians for the last ten years, managed to identify favorite expressions, topics, frequently used terms and speech habits of the politicians. For example, Nicolas Sarkozy often uses the pronoun "I ", Martine Aubry speaks of "work" and social issues; Dominique-Strauss-Kahn and Christine Lagarde, who constantly compete with each other for being seen as the 
number one expert in economic issues, often mention "France", "nation" and "immigration" in their speeches. Ségolène Royal often talks about his childhood and family; François Bayrou mentions "democracy", "people", "state", "security", "government" and "elections" in his discourse. Statehood, security and government represent the achievements of the present authorities. François Hollande's favourite word is "deficit”, Jean-François Copé's is “tax"; Olivier Besancenot often mentions Nicolas Sarkozy.

According to François Sureau (1996), politics means both attracting people and governing. Governing is apparently more difficult, it is judged according to the results. Politicians prefer attracting the masses. According to a well-known formula, politicians speak cordially. Emotional vocabulary makes speeches less transparent as a result of which political misunderstanding disappears just like the misunderstanding between lovers. Emotional vocabulary enables all the politicians to speak about themselves and about their emotions. Emotion alone is not enough. It is energy leading to victory. Politicians talk about the future of Europe, markets, competition. They think people are like plants. One should talk to them in order to prevent them from withering away. This is a dialogue.

It should be noted that there exists a kind of confrontation between politicians; they often compete and criticize each other. In order to achieve success and defeat their opponent, they tend to use a variety of adjectives, assess each other from different perspectives. At times, they even do not refrain from using abusive or insulting language, while speaking about opposition party officials. For example: Ségolène Royal says the following words about François Bayrou: he reminds me of a lover who is afraid of failure (Humour et Politique, 2008).

François Loncle Dominique writes about Villepin: - He is named after a horse participating in a horse racing though he has never run a race (Humour et Politique, 2005).

\section{DisCUSSIONS AND CONCLUSIONS}

Georgian political terminology is established by politicians. They offer new terms. It should be noted that majority of these terms are formed spontaneously. The current situation is far from an ideal one. Because of lack of consultations with specialists, some foreign terms are often used, which significantly distort the Georgian language. We believe that specialists in different fields and translators and interpreters should cooperate more closely in order to coordinate their efforts and create the appropriate terminology taking into account the rules of word formation in Georgian language. This will help us build relevant vocabulary and introduce appropriate terms in different fields.

Interpreting French political terms into the Georgian language is often problematic as far as different political systems are concerned. Despite some similarities between the French and Georgian political systems, they cannot be considered as identical. These similarities might prove to be misleading. For example the terms l'État providence-

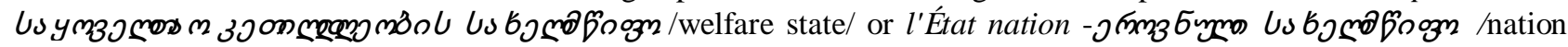
state/ belong to French political realia, which have no exact equivalents in the Georgian language. Accordingly, different versions of these terms exist in the Georgian language, which do not fully reflect the exact meaning of these terms, and therefore remain unclear to many uninformed Georgian readers. The French concept of l'État-Nation-

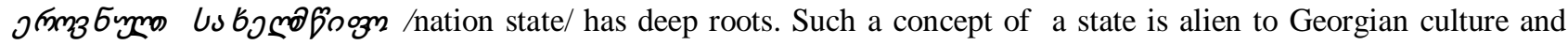
history. The context and socio-political differences should be taken into consideration while interpreting this concept in the Georgian language.

The major problem associated with the French and Georgian political terminology is that these terms are deeply rooted in the socio-cultural realities of these two countries. The problem is further aggreviated by the connotation,

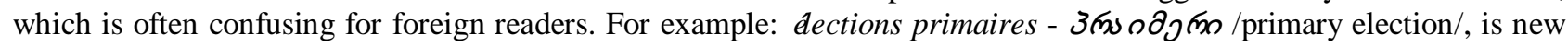
to Georgian electoral system. Primary elections allow a political party to nominate candidates for an upcoming election. Introduction of this term in the Georgian language was performed through calquing. However, the term remains unclear to the majority of Georgian readers. We believe that while using it, the term needs to be followed by an explanation.

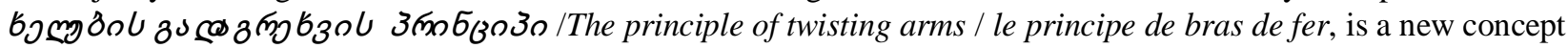
introduced in Georgian political discourse, in order to express a competition between two parties. However, its connotation remains unclear to the readers who are not familiar with the etymology of the word.

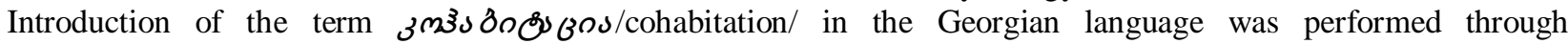
transliteration, in order to convey the idea of coexistence between a head of the state and a head of government, representing different parties.

We often have to express this or that term characteristic to our political life in the French language. For example:

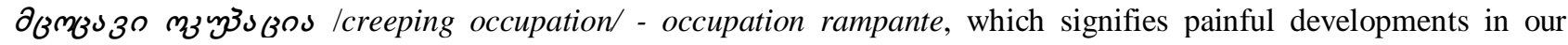
country, gradual annexation of Georgian villages by Russian soldiers and placemen of barbed wires.

We would like to single out a widely used term in Georgian political discourse; this term is: 3os mo / Public relations $(P R) /$ - Relations publiques, which is often used in various contexts in the media and by politicians. However, its definition remains a challenge. We understand that it is a very broad concept, but its use often leave readers as well as translators baffled: on om उos mo /iterally white PR; white propaganda or promotion/ (propagande blanche, une promotion /littéralement RP blanches); Zs зо उos

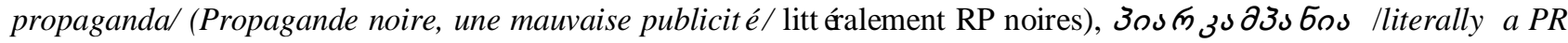


campaign a public relations campaign/ - une campagne des relations publiques. Despite the fact that they often appear in the press, translating them into French remains a challenge.

Together with the change of government in Georgia, the political discourse has undergone a significant transformation. In his political discourses, the former president of Georgia used to place a great emphasis on the progress and wonderful success which took place in Georgia after the Rose Revolution. His political discourses were predominated by the issues such as the fight against the aggressors and the country's pro-Western aspirations. For

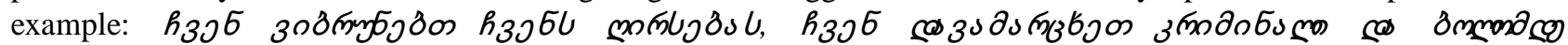

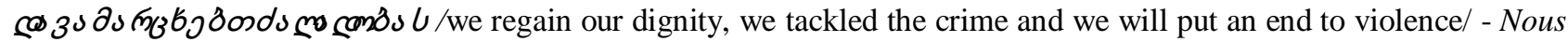
sommes en train de retrouver notre dignité, nous avons pu combattre la criminalité et nous allons finalement combattre

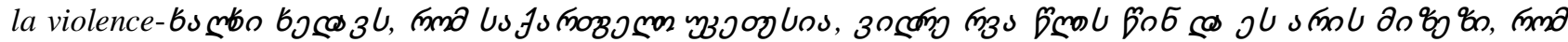
3os (mon fo 6 /People see that Georgia is better than eight years ago and this is the reason to move ahead/ - Les gens sont conscients que la Géorgie est meilleure qu'elle ne l'était il ya 8 ans, et c'est la raison principale de poursuivre le chemin trace.

The former prime minister focused on terror and injustice that prevailed in the country, as well as on respect for human dignity and national traditions. For example : ...узЈn of

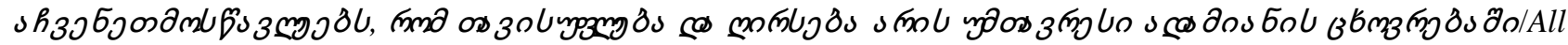
of you should rely on your conscience and show the students that freedom and dignity are essential values in human life/ - Je vous appelle chacun à suivre votre propre conscience et montrer aux élèves que la liberté et la dignité sont des

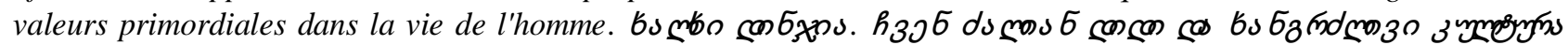

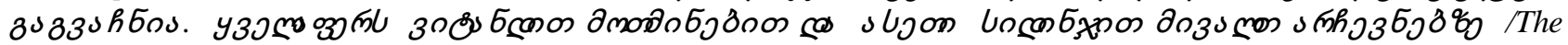
Georgian people are wise. Our country has a great history and a long-standing culture. We showed great patience and we will participate in the elections in the same spirit of perseverancel - Le peuple géorgien est sage. Notre pays a une longue histoire. Nous avons fait preuve d'une grande patience et nous irons aux élections dans le même esprit de persévérance.

In fact, a target group should always be considered and the terms used should be tailored and adapted to the knowledge of the listeners and readers. The context should be considered in order to find the exact equivalent of the term and load a political term with maximum denotation and connotation.

In conclusion, it can be said that political vocabulary varies from country to country. Each political culture creates its own vocabulary based on its history, structures and complex parameters affecting the social life of the community. Political vocabulary is distinguished by its pragmatic meaning, and by the fact that it does not necessarily reflect the existing situation. The most important feature of the political vocabulary is its increased sensitivity to changes in the life of the state. At the same time, we should not forget the linguistic factors that affect the formation of lexical units. Though, it is an incentive that brings linguistic tools into action. Extralinguistic factors play the main role in the formation of political vocabulary, and mass media significantly contributes to the development of the political vocabulary, as it represents the immediate environment of political communication.

\section{REFERENCES}

[1] Cabré, M. T. (1998). La terminologie. Théorie, méthodes et applications, Collection : U Linguistique, Armand Collin.

[2] Denquin, J.-M. (1999). Vocabulaire politique, Que sais-je? Paris, France : Presses Universitaire de France.

[3] Deshayes, B. (2011). Vocabulaire politique: voici les mots qu'ils utilisent le plus http://www.linternaute.com/actualite/politique/vocabulaire-politique.shtml_(accessed 26/03/2014).

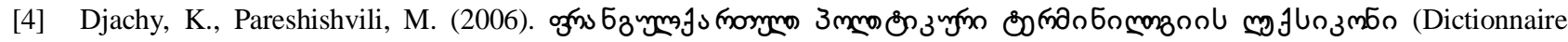
français-géorgien des termes politiques), Tbilisi, Lingua Plus.

[5] Gauthier, G. La métaphore guerrière dans la communication politique http://sitestest.uclouvain.be/rec/index.php/rec/article/viewFile/341/321 (accessed 02/04/2014).

[6] Johnson, M. et Lakoff, G. (1985). Les métaphores dans la vie quotidienne, (M. Defornel et J.-J. Lecercle, trad.), Paris: Éd. de Minuits (Ouvrage original publié en 1980 sous le titre Metaphors we live by, Chicago: The U. of Chicago).

[7] Mareshal, G. (1988). Meta : journal des traducteurs / Meta: Translators' Journal, vol. 33, n 2, pp. 258-266.

[8] Sheigal, E. I. (2000). La sémiotique du discours politique (Semiotika politicheskogo diskursa), Volgograd : Peremena.

[9] Sureau, F. (1996). Le vocabulaire de la politique. http://www.lexpress.fr/informations/le-vocabulaire-de-lapolitique_613617.html (accessed 17/04/2014).

[10] Tenzer, N. (1991). La Politique, Que sais-je ?, Paris, France : Presse Universitaire de France.

[11] Teun Van Dijk. (2006). «Politique, Idéologie et Discours », Semen [on line], 21, URL : http://semen.revues.org/1970, (accessed 20/04/2014). 


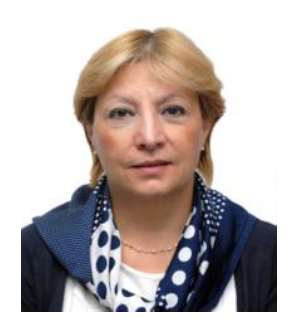

Ketevan Djachy was born in Tbilisi, Georgia on 27 August 1956. In 1973 she has obtained the Certificate of Secondary education, honored with Gold Medal, at school N 23. In 1978 she was graduated with Bachelor degree in French Language of the Roman-German faculty at M. Lomonosov University of Moscow. In 1990 has defended Doctoral Thesis and has obtained the Diploma of PHD in comparative linguistics, Iv. Javakhishvili State University of Tbilisi. In 1996 has obtained the Certificate of a Docent. In 2002 has defended Thesis of Habilitation and has obtained the Diploma of a Doctor of Sciences in Romance philology, Iv. Javakhishvili State University of Tbilisi.

She was Teaching Assistant in Ilia Chavchvadze State Institut of Foreign Languages of Tbilisi. In 1996 she has conferred the scientific-pedagogical title of the Docent. From 2002 to 2006 she was Professor FLE /LEA at the Branch of Paul Valéry State University of Montpellier III of Ilia State University of Tbilisi. Since 2006 she is Full Professor of Ilia State University of Tbilisi. Since 2003, she is member of Special research group 4509, "Sense, Text, Computer, History", in Sorbonne University (Paris IV). She had participated in 10 International Conferences. She had obtained beneficiary grants of individual mobility 6 times. In 2000, she took the 3th place in Competition among Universities' Profess ors, held by Embassy of France and was awarded with prize. She took part participated in Trainings (2009 course for Trainer of Information's Technology - Passport TIC, Transfer-Georgia-Tbilisi, organized by AUF, 1999- organized by Embassy of France and Georgian Ministry of Education, 1992-“Language, Culture, Methodology”, for Teachers, in "Alliance Française" in Paris, France). In 1997, she has participated in three broadcasts on the "France Culture" and two TV broadcasts on "France 2" in Paris.

Since 1994 she is Simultaneous Interpreter (French-Georgian-French, Russian-French) and has participated in International Conferences, organized by International organizations, as BSEC, PABSEC, UNESCO, TAD, NATO, Council of Europe, dedicated to political, economical, law, social issues. Author of 18 books and 55 articles:

1.K. Djachy, M. Pareshishvili, The terms of translation of political newspaper articles headlines from French to Georgian, (in English) in USA \& Sino-US English Teaching, EBSCO, Ulrich; 2012, volume 10, serial number 2, February, pp. 966-973;

2.K. Djachy, N. Lomia, Characteristics of Expression of basic Emotions in Italian, Literary texts of XX century, (in English), in USA \& Sino-US English Teaching, EBSCO, Ulrich 2012, volume 10, serial number 3, March, pp. 1050 - 1060.

3. K. Djachy, M. Pareshishvili, Realia as Carriers of National and Historical Overtones, Theory and Practice in Language Studies, Vol. 4, No. 1, pp. 8-14, January 2014 @ 2014 ACADEMY PUBLISHER.

Prof. Djachy is Member of scientific and editorial board of International Iranian Review "Le Linguiste" and

Member of International Organizations (Since 2012-0EP, CIEF, Since 2010-TIA, 2006-Group LTT of AUF). She has been Member of Doctorate Board (2010, 2009-Baku, 2006-Paris IV) at the international level and at the national level 40 times. In 2011 was invested as Chivalry an Order of Academic Palms, by Mr. Eric Fournier, Ambassador of France in Georgia, to contribution to French culture.

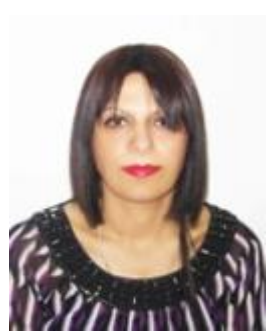

Mariam Pareshishvili was born on November 9, 1978 in Tbilisi, Georgia. In 1996 she finished school N 167. In 2001 she completed a full academic course of the Tbilisi Ilia Chavchavadze State University of Language and culture (translator-Interpreter). In 2001 she was enrolled in the Department of Simultaneous Interpretation and was granded the qualification of simultaneous Interpreter. In 2013 she defended the doctoral dissertation in translations studies (the degree of doctor of philosophy in philology) in Ilia State University in Georgia. In 2011 she has the probation in ESIT, Graduate School of Translation and Interpreting (Université de la Sorbonne Nouvelle).

From 2008 she is french teacher in Georgian University of Patriarchate. Since 2003 she was teacher of translation at the Department of Simultaneous Interpretation. Since 2003 she is simultaneous interpreter (French-Georgian-French) and has participated in Conferences, organized by International organizations.

Dr.Pareshishvili is member of International Centre for French Studies. Since 2010 she is member of Association of Translator and Interpreters. She had participated in International and local Conferences. Author of 13 scientific publications.

1. K. Djachy, M. Pareshishvili, The terms of translation of political newspaper articles headlines from French to Georgian, (in English) in USA \& Sino-US English Teaching, EBSCO, Ulrich; 2012, volume 10, serial number 2, February, pp. 966-973;

2. K. Djachy, M. Pareshishvili (2014) Realia as Carriers of National and Historical Overtones. Theory and Practice in Language Studies, Vol. 4, No. 1, pp. 8-14, January 2014 ACADEMY PUBLISHER

3. M. Pareshishvili (2014). The comparative typology of French and Georgian journalistic discourses. Theory and Practice in Language Studies. Be at the printers 